\title{
Accounting in Managerial Work
}

\section{Hamed Mehrani}

Islamic Azad University of Chaloos, Mazandaran, Iran

Correspondence Author: Hamed Mehrani Islamic Azad University of Chaloos, Mazandaran, Iran E-mail: Hamed.mehrani.2018@gmail.com

Received date: 12 May 2019, Accepted date: 24 June 2019, Online date: 28 June 2019

Copyright: (C) 2019 Hamed Mehrani . This is an open-access article distributed under the terms of the Creative Commons Attribution License, which permits unrestricted use, distribution, and reproduction in any medium, provided the original author and source are credited.

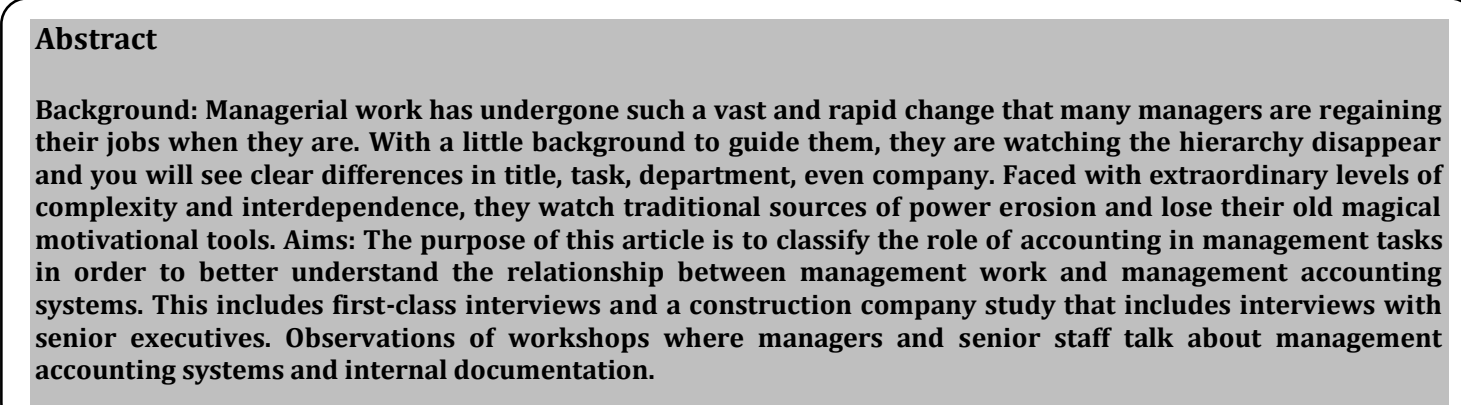

Keywords: Accounting information, Managerial work, Managers, Management Accounting Systems

\section{INTRODUCTION}

Managerial work nowadays is enduring such tremendous and fast changes that many managers will reinvent their profession as they progress. With a small background to guide them, they are watching the hierarchy disappear and you will see apparent differences in title, task, department, even company. Faced with extraordinary levels of complexity and interdependence, they watch original sources but traditional power erosion and lose their old magical motivational tools. On the other hand, a line manager directs a function that directly contributes to the products or services the organization creates. For instance, a line manager (often referred to as a product or service manager) at Procter \& Gamble (P\&G) is responsible for the production, marketing and profitability of the tide detergent product line. Instead, the staff manager directs a function that generates indirect inputs for the reviving output. For instance, finance and accounting are important organizational functions, but typically do not provide the end product or service in the last product or service the customer purchases, such as a tide detergent box. Instead, they play a supportive role. A project manager is responsible for planning, executing and closing each project. Project managers are usually shown in construction, architecture, consulting, computer networks, telecommunications or software development. The progress of management science depends on our understanding of the manager's business processes. A review of the literature shows that this understanding is at best superficial. The empirical study of the work of five managers supported by the research findings that are available led to the following explanation.

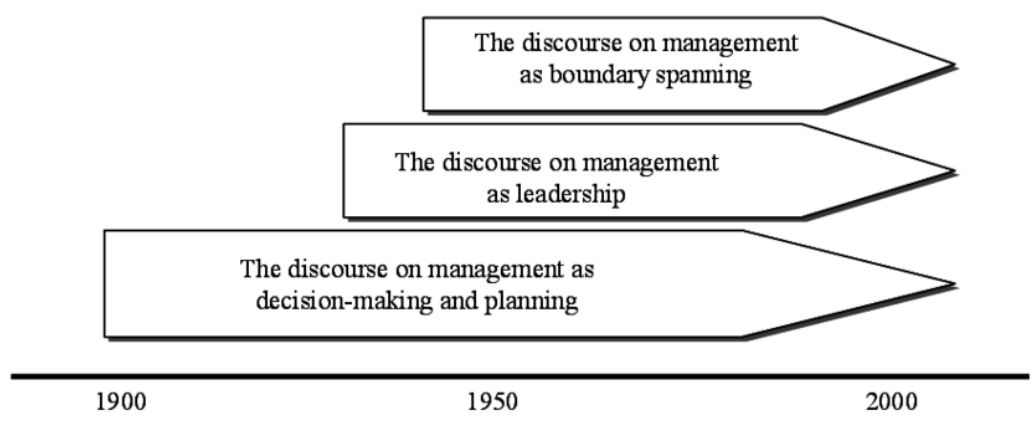

Fig. 1 Managerial Work Progress 


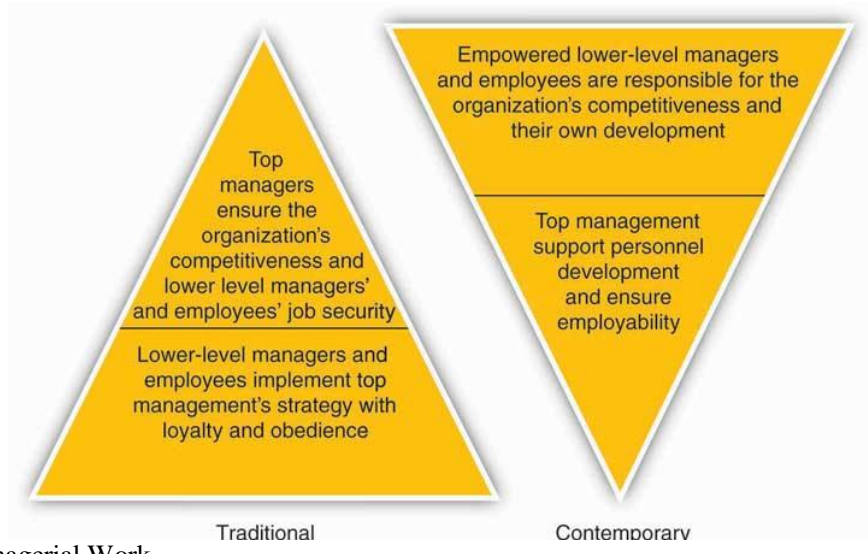

Fig. 2 Traditional and Contemporary Managerial Work

Contemborarv

Accounting is the measurement, processing, and relevance of financial and non-financial information about economic entities [1-5] such as businesses and corporations. Accounting can be sub-divided into many areas such as financial accounting, management accounting, external audit, tax accounting and cost accounting. [6] [7] Accounting information systems are introduced to support accounting functions and related activities. Financial accounting focuses on reporting an organization's financial information, including preparing financial statements to external users of information such as investors, regulators and suppliers. Information for internal use by management

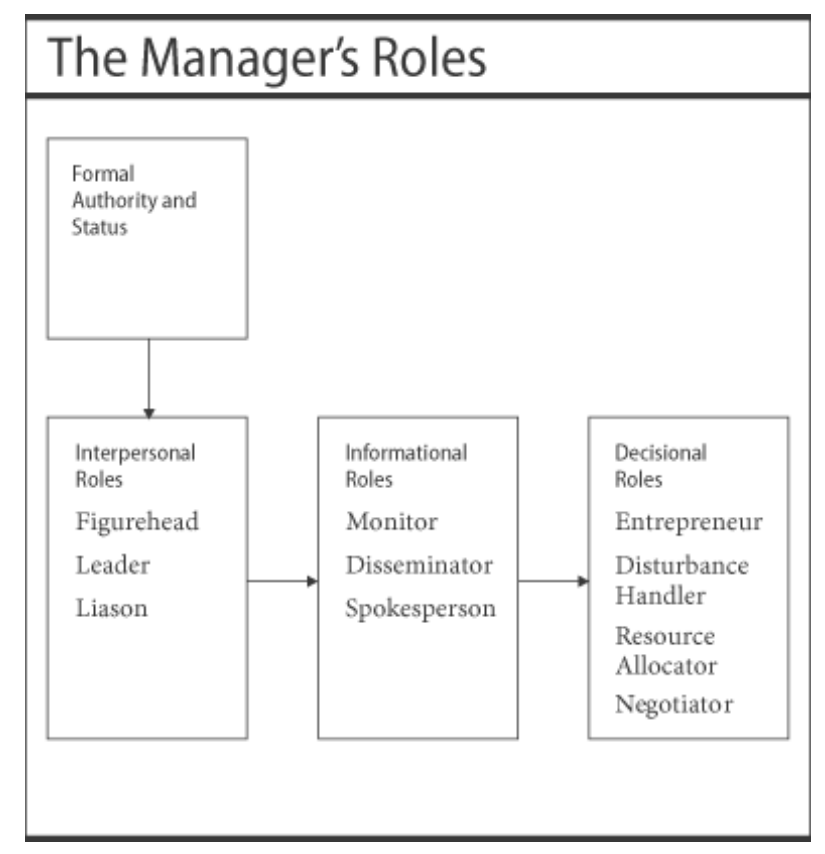

Fig. 3 The Managerial Work

Management accounting focuses on measuring, analyzing, and reporting information that can be used by the managers make decisions about achieving an organization's goals. In management accounting, internal measures and analysis-based reporting are cost-effective and do not need to comply with the GAAP. [8] In 2014, CIMA developed the principles of Global Management Accounting (GMAP). The result of research from 20 countries across five continents is aimed at guiding the best practices in the field. [7] Management accounting produces forward-looking reports - for example, the 2006 budget was prepared in 2005 - and the reporting time is very different. These reports may include financial and non-financial information, and may, for example, focus on specific products and sectors. [8] Auditing is the affirmation of others' claims for reimbursement, [8] and in the context of accounting, "the unbiased review and evaluation of an organization's financial statements". [8] On the other hand, auditing is a professional service that is orderly and regular. [9] An audit of financial statements is intended to express or disagree with financial statements. The auditor submits his opinion on the fairness that the financial statements present in the financial statements, results of operations and cash flows of an entity, in accordance with the generally accepted accounting principle (GAAP) and "in all respects".. The auditor is also required to identify situations where generally accepted accounting principles (GAAP) are not consistently observed.

Hence, assuming the above, managers are assumed to cite a number of information-related tasks, such as problem-solving [10-13], interactive control, planning [10], and performance evaluation. However, there is evidence that formally designed management accounting systems do not always meet the needs of managers. Hypothetical, integrated, and one-way accounting information is considered monetary, confirming what managers know rather than providing new insights, and usually require managers to use complementary resources to do their job (e.g. Example [2, 6, 10-13]).

\section{METHODOLOGY}

The purpose of this article is to classify the role of accounting in management tasks to better understand the relationship between management work and management accounting systems. This includes first-class interviews and a construction company study that includes interviews with senior executives. Observations of workshops where managers and senior staff talk about management accounting systems and internal documentation. 


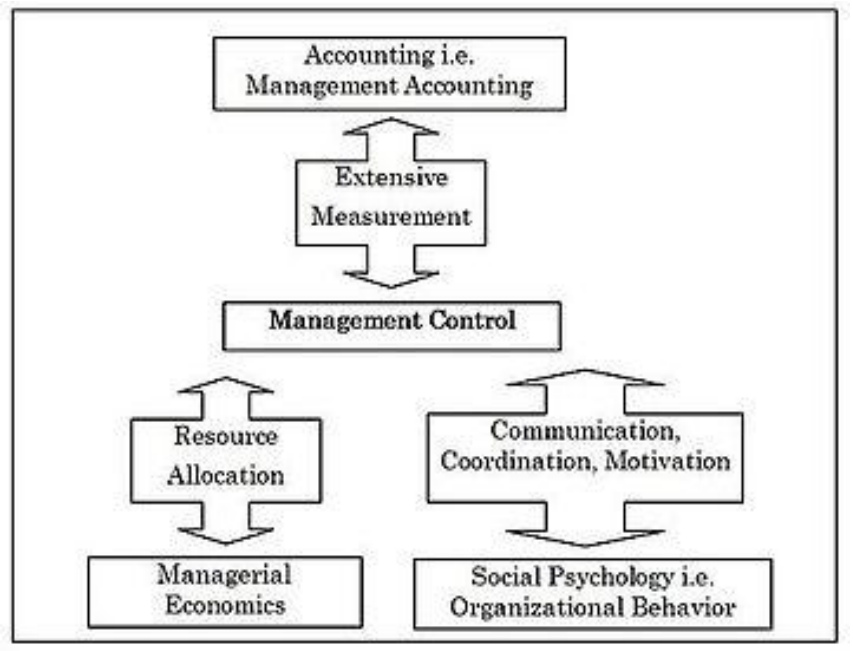

Fig. 4 Management Accounting

This article explores the appearing literature on the use of accounting information by managers and discusses IT and management accounting. A total of 25 interviews with managers were extracted at five levels of hierarchy: one five deputy managers, five district managers, five district managers, five project managers and five production managers. Production managers were responsible for the costs, while other managers were responsible for the profits. They were all responsible for the personnel. The interviewees were almost "representative" of the two business units that this article decided to focus on, as well as larger and smaller cities in different geographical areas of Iran. Interviews are similar to the interviews conducted in this study. Similarly, they were semi-structured on animation topics, but with the flexibility of the interviewer and the interviewee to discuss other things that seemed to be a slightly appearing method, this meant that some questions in the Length of the interview.

\section{Professional Accounting and Management Profession}

Tensions between staff and operational managers later became apparent. Operations managers seemed to retain employees' attitudes as ordinary, hard-working individuals with "real life" relationships, while employees seemed concerned that managers valued operations, systems, and other support tools. . This seems to be the case of classical stress between central and local values [15-13] or between different performance dependencies [16].

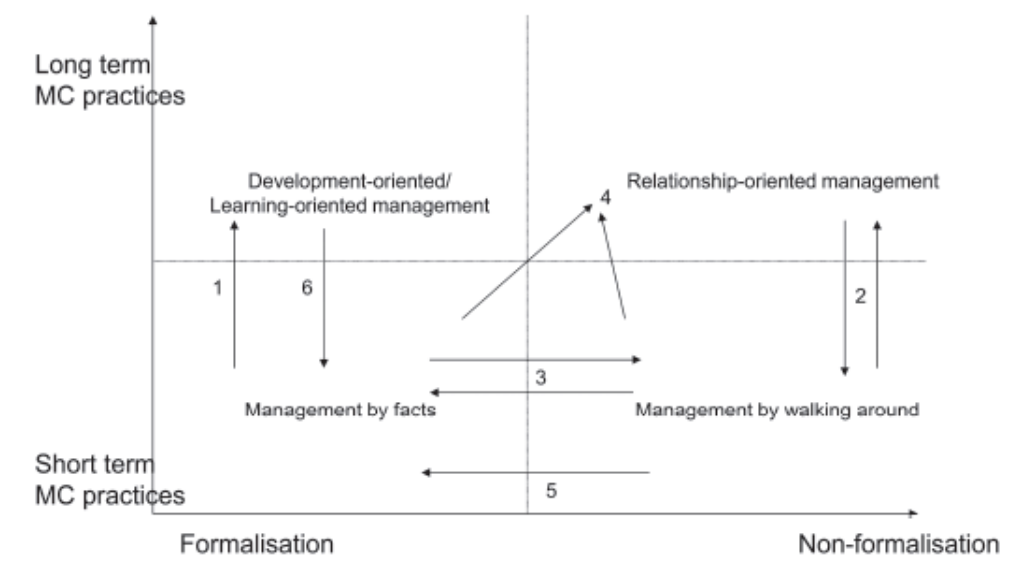

Fig. 5 Time Horizon and Degree of Formalisation

\section{Percent}

34 Not yet begun

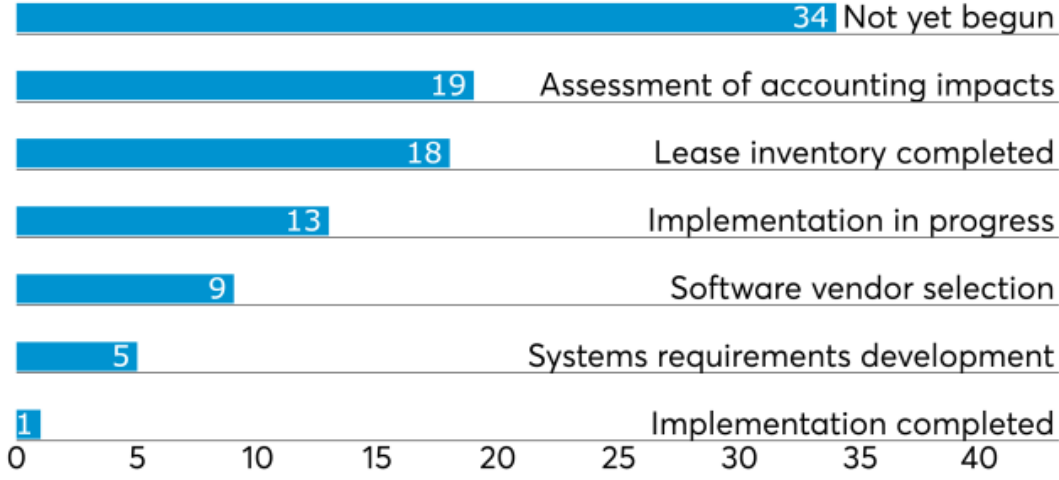

Fig. 6 Leas Accounting Readiness

\section{CONCLUSIONS}

Although accounting management and public administration issues appear to be intertwined, and however accounting information is incidental in management, managers tend to choose accounting information as part of their accounting management. Considering accounting management as one of the "bottom line" quota, interacting with accounting information may seem to be output or input activities that managers value more. Besides, it is essential to know that the different parts of the whole "chart" are different in various characters and require different skills, as switching between them may be recognized by managers as a cost. Even with 
the best of provider goals, such as a balanced scorecard or a graphical data recovery interface, administrators may feel that these reports and tools are just something else on the to-do list, not what they support. This does not mean that accounting information is not done, but with a separate diagram of the different nature of competition-based tasks, accounting information may be more visible to those working with these tools. Therefore, it may be essential to find "natural" accounting methods in other areas of management work, for example through the use of mobile devices to report data or send accounting information to the physical workplace.

[1] Alvesson, M. \& Kärreman, D. (2007). Constructing mystery: Empirical matters in theory development. Academy of Management Review, 32(4), 1265-1281.

[2] Andon, P. Baxter, J. \& Chua, W.F. (2007). Accounting change as relational drifting: A field study of experiments with performance measurement. Management Accounting Research, 18(2), 273-308.

[3] Ansari, S. \& Euske, K.J. (1987). Rational, rationalizing, and reifying uses of accounting data in organizations. Accounting, Organizations and Society, 12(6), 549-570.

[4] Bryer, A.R. (2011). Accounting as learnt social practice: The case of the empresas recuperadas in Argentina. Accounting, Organizations and Society, 36(8), 478-493.

[5] Carlile, P.R., Nicolini, D., Langley, A. \& Tsoukas, H. (2013). How matter matters: Objects, artifacts, and materiality in organization studies. Oxford Scholarship Online.

[6] Corradi, G., Gherardi, S. \& Verzelloni, L. (2010). Through the practice lens: Where is the bandwagon of practice-based studies heading? Management Learning, 41(3), 265-283.

[7] Funck, E. (2007), The balanced scorecard equates interests in healthcare organizations. Journal of Accounting and Organizational Change, 3(2), 88-103.

[8] Geiger, D. (2009). Revisiting the concept of practice: Toward an argumentative understanding of practicing. Management Learning, 40(2), 129-144.

[9] Jørgensen, B. \& Messner, M. (2010). Accounting and strategizing: A case study from new product development. Accounting, Organizations and Society, 35(2), 184-204.

[10] Kald, M., Nilsson, F. \& Rapp, B. (2000). On strategy and management control: The importance of classifying the strategy of the business. British Journal of Management, 11(3), 197-212.

[11] Kotter, J.P. (1982). What effective general managers really do. Harvard Business Review, 60(6), $156-167$.

[12] Langefors, B. (1995). Essays on infology: Summing up and planning for the future. Lund: Studentlitteratur.

[13] Orlikowski, W.J. \& Iacono, C.S. (2001). Research commentary: Desperately seeking the "IT" in IT research - A call to theorizing the IT artifact. Information Systems Research, 12(2), 121-134.

[14] Otley, D.T. \& Berry, A.J. (1980). Control, Organisation and Accounting. Accounting, Organzations and Society, 5(2), $231-244$.

[15] Pfeffer, J., \& Sutton, R.I. (2006). Hard facts, dangerous half-truths, and total nonsense: Profiting from evidence-based management. Boston: Harvard Business School Press. 